\title{
Ibn Baț̣ūṭa. \\ Średniowieczny mistrz reportażu i pierwszy arabski globtroter
}

DOI: http://dx.doi.org/1 0.12775/LC.2019.012

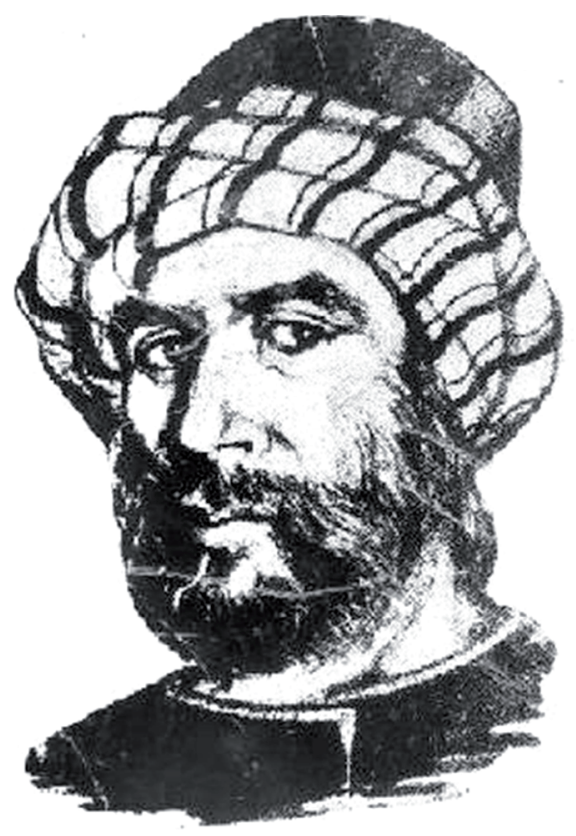

Ibn Batṭūṭa ${ }^{1}$

* Dr hab. nauk humanistycznych w zakresie literaturoznawstwa, pracuje w Instytucie Filologii Wschodniosłowiańskiej na Wydziale Filologicznym Uniwersytetu w Białymstoku. E-mail: g.czerwinski@uwb.edu.pl.

1 Zob. https://www.marefa.org/ [15.06.2017]. 
ematyka średniowiecznych podróży do krajów orientalnych kojarzy się w pierwszej kolejności z postacią Marco Polo (1254-1324). Wenecki kupiec i podróżnik przemierzył niemalże cały kontynent azjatycki: przez Bliski Wschód i Azję Centralną dotarł lądem do wybrzeży Oceanu Spokojnego, by drogą morską udać się ponownie do Persji, skąd powrócił do ojczystej Republiki Weneckiej. W swoim monumentalnym dziele zatytułowanym Le divisament dou monde (przekład polski: Polo 1954) Marco Polo twierdzi, że był pierwszym Europejczykiem zapuszczającym się w głąb Azji (Bergreen 2008: 72-78). Współcześnie wiadomo jednak, że przed wędrówką sławnego Wenecjanina podróże do krajów Orientu odbyli m.in. Beniamin z Tudeli (Dulska 2015), który trzy lata spędził w Bagdadzie (1160-1173), oraz franciszkanie Giovanni di Piano de Carpini i Benedykt Polak (Strzelczyk 1993), wysłani z misją ewangelizacyjną do Karakorum (1245-1247).

Legenda Marco Polo przyćmiła dokonania innego wielkiego podróżnika - wywodzącego się ze świata muzułmańskiego Ibn Bațtūty (1304-1377). Pełne nazwisko urodzonego w Tangerze na terenie ówczesnego państwa Marynidów średniowiecznego globtrotera brzmiało Abū 'Abd Allāh Muḥammad Ibn 'Abd Allāh al-Lawātī aṭ-Ṭanğĩ. Ananiasz Zajączkowski „rozszyfrowując” znaczenie nazwiska, wskazuje:

Właściwym imieniem (w naszym ujęciu) autora było dość pospolite wśród muzułmanów imię Mohammed; pierwsza część przytoczonej formy Abu Abd Allah stanowi tak zwaną kunję, czyli nazwę urobioną od imienia syna, zatem „ojciec Abd Allaha”, wreszcie na końcu dwie tak zwane nisby, czyli określenie pochodzenia, pierwsza na oznaczenie przynależności etnicznej: al-Lawati - „pochodzący z berberyjskiej grupy plemiennej Lawata (po berberyjsku Ilawaten), oraz ostatnia (druga) - at-Tandżi, wskazująca na pochodzenie geograficzne z miasta Tangeru (Zajączkowski 1962: VIII).

Zajączkowski rekonstruuje ponadto etymologię przydomka Ibn Baț̣uṭa. W języku arabskim oznacza on oczywiście „syn Batțūty”, jednakże polski orientalista pokazuje, że w przekładzie z arabskiego formę „baț̣uța” można tłumaczyć jako „kaczuszka” (ibid.: VIII). Syn kadiego Tangeru (taką funkcję pełnił ojciec podróżnika) bywa także nazywany Šams ad-Dīn, co oznacza „Słońce Wiary” (ibid.).

W młodości Ibn Bațūṭa studiował prawo muzułmańskie rozpowszechnionej w Afryce Północnej szkoły malikickiej (Yagi 2004: 16-18). W wieku 21 lat zdecydował się odbyć pielgrzymkę do świętych miejsc islamu - Mekki i Medyny. Przyszły globtroter wyruszył 14 czerwca 1325 roku w kierunku Półwyspu Arabskiego, nie przeczuwając z pewnością, że jego hağğ przemieni się w trwającą prawie trzydzieści lat (1325-1354) podróż dookoła (muzułmańskiego) świata. W ciągu całego życia Ibn Baț̣uṭa przebył ponad 73000 mil (117500 km), odwiedzając tereny 44 współczesnych państw (Bently 1993: 114). Jego relacja w pierwszym wydaniu europejskim liczy cztery tomy, które ukazywały się kolejno w latach 1853, 1854, 1855 i 1858 (Defrémery et al. 1853-1858)².

\footnotetext{
2 Korzystam z wydania internetowego tej książki: http://remacle.org/bloodwolf/arabe/batoutah/voyage. htm [26.04.2017].
} 
Ekskursje marokańskiego podróżnika, które doczekały się szerokiego omówienia w literaturze naukowej ${ }^{3}$, można podzielić na cztery okresy, wyznaczane kolejnymi pielgrzymkami do Mekki:

1) 1325-1327: pielgrzymka do Mekki przez wybrzeże Maghrebu oraz Egipt (Aleksandria, Damietta), a także odwiedziny Syrii (Damaszek, Aleppo, Antiochia, Latakia), Palestyny, Iraku (Al-Basra, Mosul, Al-Kufa) i Persji (Isfahan, Sziraz) oraz powrót do Mekki;

2) 1328-1330: druga pielgrzymka do Mekki, dwuletni pobyt w Arabii, zwiedzanie obszarów Zatoki Perskiej (Jemen, Oman), wyprawa morska do Zanzibaru oraz powrót do Kairu;

3) 1330-1349: trzecia pielgrzymka do Mekki, podróż przez rejony basenu Morza Czarnego (Anatolia, Krym, Stepy Kipczackie), Azję Centralną (Chorezm, Chorasan, Afganistan), Indie (Multan, Sistan, Delhi, Himalaje), Cejlon, Chiny (Kanton, Quanzhou, Żółta Rzeka, Hangzhou, Pekin) i Sumatrę, skąd drogą morską płynie do Arabii w 1347 roku, a po kolejnym odwiedzeniu Persji, Syrii i Egiptu udaje się na czwartą pielgrzymkę do Mekki i w 1349 roku powraca do Maroka;

4) 1349-1354: podróż do Grenady, a następnie przez Saharę do Sudanu Zachodniego i Mali.

Powyżej wskazałem najważniejsze krainy i, co chciałbym podkreślić, tylko wybrane miasta odwiedzone przez Ibn Baț̣ūtę. Sporządzenie całego katalogu miejsc, w których przebywał marokański podróżnik, wymagałoby odrębnego opracowania.

Dokonania Ibn Batțūty zadziwiają nie tylko rozmachem przestrzennym jego peregrynacji. Publikacje geografa-amatora $\mathrm{z}$ Tangeru stanowią moment przełomowy dla kultury i wiedzy geograficznej świata arabskiego - należy podkreślić, że przed Marokańczykiem nie było żadnego podróżnika wywodzącego się z muzułmańskiego Orientu, który by własny krąg kulturowy przedstawił w tak szerokim ujęciu. Ibn Bațūụta pozostawił po sobie monumentalne dzieło, zaliczane przez badaczy literatury arabskiej do gatunku rihla (Dziekan 1998: 105; Dunn 2004: 310), które jest nie tyle opisaniem krajów, co dogłębną charakterystyką społeczeństw i kultur. Pisarz występuje więc w Osobliwościach miast i dziwów podróży przede wszystkim jako baczny obserwator życia codziennego.

Nie znaczy to jednak, że narracja Ibn Batțūty nosi cechy poetyzowanego dyskursu socjologiczno-antropologicznego. Arabski podróżnik zdaje się opisywać tylko to, co go oczarowuje i zadziwia, co przynależy do sfery kultu muzulmańskiego bądź wiąże się z jakąś nieokreśloną przestrzenią niezwykłości (por. Zajączkowski 1962: XIV). Niemniej jednak to właśnie tak ukształtowany punkt widzenia narracji decyduje o oryginalności dzieła Marokańczyka, gdyż świat muzułmański (lub indyjski czy też chiński świat innowierców $\mathrm{w}$ konfrontacji $\mathrm{z}$ islamem) został przedstawiony w jego utworze przez pryzmat świadomości wyznawcy islamu. Autorowi udało się przeniknąć sferę niedostępną dla wywodzących się z europejskiego kręgu kulturowego podróżników późniejszych epok (por. Kraczkowski 1957: 417; Zajączkowski 1962: VII). Co ciekawe, Osobliwości miast zostały spisane nie przez samego geografa, lecz przez sekretarza Ibn Battuty - pochodzącego z Grenady Ibn

3 Spośród bogatej literatury na ten temat chciałbym wskazać: Miłosławski 1974; Timofiejew 1983; Ibragimow 1988; Waines 2010. Podróże arabskiego podróżnika chronologicznie omawia także A. Zajączkowski we wstępie do polskiego wydania pism Ibn Bațūțy (Zajączkowski 1962). 
Ğuzayya (1294-1340). Fakt ten kolejny raz ukazuje podobieństwo twórczych losów Ibn Bațtūty i Marco Polo, którego Opisanie świata zredagowal pisarz znany pod imieniem Rusticello z Pizy.

Dzieło arabskiego autora składa się z rozdziałów prezentujących jego podróże w porządku chronologicznym, podzielonych na ustępy o charakterystycznych tytułach, takich jak np.: „Opis latarni morskiej”, „,Opis wielkiej i czcigodnej Kaaby”, „Opis muru i bram Delhi” czy też „O wielkiej chatum”, „O wspaniałomyślności onego króla”, „O tym, jak emir Gada został uwięziony". Wydzielone ustępy prezentują opisy miast (przykładowo Konstantynopola czy Delhi), meczetów lub innych budowli (grobowców, jak choćby w Szirazie czy Basrze, kościołów w Konstantynopolu $)^{4}$. Czytelnik dzieła dowiaduje się także szczegółów na temat świętych miejsc islamu. W tekście znajdujemy opisy Al-Ka 'by, źródła Zamzam, zaznajamiamy się z elementami ḥağğu. Niekiedy pojawiają się też w toku narracji opisy przyrody - są to jednak nie tyle charakterystyki pejzażu lub opisy zjawisk, ile wybranych elementów natury ożywionej (drzew owocowych w Indiach czy też krzewu pieprzowego).

Ważnym komponent utworu stanowią prezentacje spotykanych ludzi, najczęściej władców lub dostojników muzułmańskich (emir Multanu, władca Indii itd.). Opisy bohaterów są zwykle połączone u Ibn Bațūty z opowieściami o wydarzeniach, w których owi bohaterowie brali udział. W taki sposób od czystego prezentyzmu przechodzi autor do kreślenia własnych obserwacji natury społeczno-kulturowej. Katalog tematów podjętych przez podróżnika wydaje się nie mieć końca. Po pierwsze, dowiadujemy się z jego dzieła, jak wyglądają rytuały innowierców (np. palenie zwłok przez Hindusów). Po drugie, poznajemy zwyczaje panujące w różnych zakątkach Afryki i Azji, stroje narodowe i potrawy. Po trzecie w końcu, zaznajamia nas Ibn Baț̣uṭa ze sferą życia codziennego wybranych ludów (za ciekawostkę można uznać chociażby informację o sposobach wyrobu torfu w Chinach).

Odrębne miejsce w narracji Ibn Baț̣utty zajmują ustępy nazwane przez autorów polskiego przekładu „opowiadaniami” (w przekładzie francuskim występują jako anecdotes, a więc „anegdotki”, „dykteryjki”, „historyjki”). Owe „dykteryjki”, odwołując się do tradycji zachodniego literaturoznawstwa, można by pomieścić gdzieś między bajką i krótką legendą o rysach humorystycznych. Są to zasłyszane przez autora opowieści, nieraz o symbolicznym charakterze, przedstawiające jakieś wyjątkowe wydarzenie. W niektórych przypadkach świadkiem takiej historii był sam Ibn Bațtūṭa. Bardzo często „anegdoty” są związane z opisami bohaterów występujących w tekście. Postrzegane całościowo, jako zbiór „opowieści”, mogą świadczyć o głębokiej indywidualizacji stylu Ibn Batțūty, a także o poczuciu humoru i nieraz ironicznym dystansie (przynajmniej tak, jako badacz literatury współczesnej, to odbieram) autora. Najciekawsze według mnie „dykteryjki” dotyczą relacji katolicko-muzułmańskich w będącej pod panowaniem Genueńczyków Kaffie (Teodozji) na Krymie oraz fascynacji poetyckich Ğalāl ad-Dīna.

Dzieło Ibn Bațtūty za sprawą swej osobliwości oraz bogactwa zawartych wiadomości jest nie tylko aktualnym wciąż źródłem informacji (a czasem jedynym źródłem historycznym na dany temat, jak np. w przypadku Złotej Ordy) (Zajączkowski 1962: XV), ale też

\footnotetext{
${ }^{4}$ Opisy te, co ważne, nie straciły nic z aktualności, jeśli porównamy je do relacji XX-wiecznych podróżników europejskich. Co więcej, Ibn Bațūța, choć może nie daje nam syntetycznego ujęcia danego zjawiska, raczy czytelnika spojrzeniem świeżym i przenikliwym. Jego obserwacje są częstokroć bardziej zindywidualizowane niż zapisy relacji współczesnych autorów posiłkujących się przewodnikami lub zaczytujących się w lekturach swoich poprzedników.
} 
ciekawą przygodą czytelniczą, nie mniej fascynującą niż dzieła współczesnych mistrzów reportażu podróżniczego, w wielu aspektach bardziej wartościową od zapisów innych peregrynantów epoki (europejskiego) średniowiecza.

\section{Bibliografia}

Bently, Jerry 1993. Old World Encounters. Cross-Cultural Contacts and Exchanges in Pre-Modern Times. New York: Oxford University Press.

Bergreen, Laurence 2008. Marco Polo. Od Wenecji do Xanadu. Tłum. Marta Dziurosz. Poznań: Rebis.

Dulska, Anna Katarzyna 2015. Diaspora żydowska na Bliskim Wschodzie oczami sefardyjskiego podróżnika Beniamina $z$ Tudeli. Kraków: Księgarnia Akademicka.

Dunn, Ross E. 2004. The Adventures of Ibn Battuta, a Muslim Traveler of the Fourteenth Century. Oakland-Berkeley: University of California Press.

Dziekan, Marek M. 1998. Polacy a świat arabski. Gdańsk: Związek Tatarów RP.

Ibn Battuta 1962. Osobliwości miast i dziwy podróży 1325-1354. Wybór. Tłum. z ar. Tadeusz Majda, Halina Natorf. Red. nauk., wybór i przedm. Ananiasz Zajączkowski. Koment. oprac. Tadeusz Majda. Warszawa: Książka i Wiedza.

Ibragimow, Niematułła 1988. Ibn Battuta i jego putieszestwija po Sriedniej Azii. Moskwa: Nauka.

Kraczkowski, Ignatij 1957. Izbrannyje soczinienija w 6 tt. Tom 4: Arabskaja gieograficzieskaja litieratura. Moskwa-Leningrad: Izdatiel'stwo AN SSSR.

Miłosławski, Gieorgij 1974. Ibn Battuta. Moskwa: Mysl'.

Polo, Marco 1954. Opisanie świata. Z oryg. starofr. z uwzględnieniem red. starowt. i łac. thum. Anna Ludwika Czerny. Wstępem i przypisami opatrzył Marian Lewicki. Warszawa: Państwowy Instytut Wydawniczy.

Strzelczyk, Jerzy (red.) 1993. Spotkanie dwóch światów. Stolica Apostolska a świat mongolski w potowie XIII wieku. Relacje powstate w związku $z$ misja Jana di Piano Carpiniego do Mongotów. Poznań: Abos.

Timofiejew, Igor 1983. Ibn Battuta. Moskwa: Mołodaja gwardija.

Voyages d'Ibn Batoutah 1853-1858. Texte arabe, acompané d'une traduction par C. Defrémery et B.R. Sanguinetti. Vol. 1-4. Paris: Société Asiatic.

Waines, David 2010. The Odyssey of Ibn Battuta: Uncommon Tales of a Medieval Adventurer. Chicago: University of Chicago Press.

Yagi, V. Amina 2004. Droit musulman. Paris: Publisud.

Zajączkowski, Ananiasz 1962. „Ibn Battuta i jego dzieło”. W: Ibn Battuta. Osobliwości miast i dziwy podróży 1325-1354. Wybór. Tłum. z ar. Tadeusz Majda i Halina Natorf. Red. nauk., wybór i przedm. Ananiasz Zajączkowski. Koment. oprac. Tadeusz Majda. Warszawa: Książka i Wiedza. 